\title{
Pengaruh Perilaku Pemimpin dan Komitmen Karyawan Terhadap Prestasi Kerja Karyawan Pada Puskesmas Desa Aro Kecamatan Muara Bulian
}

\author{
Niki Kosasih \\ Sekolah Tinggu Ilmu Ekonomi Graha Karya
}

\begin{abstract}
The title of this study is the Effect of Leader Behavior and Employee Commitment on Employee Work Achievement at Village Aro Health Center, Muara Bulian District. The Effect of Leader Behavior and Employee Commitment is treated as an independent variable and Employee Work Performance is treated as the dependent variable. This study aims to (1) To clarify the description of leader behavior (2) To clarify the picture of employee commitment (3) To clarify the description of employee work performance (4) To analyze the influence of Leader Behavior and Employee Commitment on Work Performance of Village Aro Community Health Center Muara Bulian District . The method used is the survey method. The population as well as samples in this study were 43 respondents. Data collection is done by distributing questionnaires to respondents. Data were analyzed using descriptive statistical analysis and analysis involving the determination of the regression coefficient correlation test. The results of this study indicate that (1) Leader behavior variables based on questions the average value of the 5 indicator indicators amounted to 3.48, it can be seen the respondent answered agree. (2) The leader behavior variable based on the question of the average value of the 5 question indicators is 3.34 so that the respondents can answer neutral. (3) Work performance variables based on the questions of the average value of the 5 question indicators amounted to 3.48, so the respondents answered neutral. (4) Leader Behavior and Employee Commitment have a positive and significant effect on Employee Performance at the Aro Village Health Center, Muara Bulian District, which is $76.6 \%$.
\end{abstract}

Keywords: Leader Behavior; Employee Commitment; Employee Performance; Village Aro Health Center

DOI: 10.33087 /ekonomis.v3i1.53

\section{PENDAHULUAN}

Pembangunan Nasional dilaksanakan dalam rangka membangun manusia Indonesia seutuhnya dan seluruhnya. Menyadari bahwa tercapainya tujuan pembangunan nasional merupakan kehendak dari seluruh rakyat Indonesia dan dalam rangka menghadapi makin ketatnya persaingan bebas pada era globalisasi, upaya peningkatkan kualitas sumber daya manusia harus dilakukan semaksimal mungkin. Era reformasi dan dampak persaingan globalisasi mendorong percepatan perubahan perbaikan kinerja aparatur pemerintah. Aparatur pemerintah dituntut bekerja lebih professional, bermoral, bersih dan beretika dalam mendukung reformasi birokrasi dan menunjang kelancaran tugas pemerintahan dan pembangunan. Reformasi birokrasi saat ini sedang berlangsung di semua lini lembaga pemerintah baik tingkat pusat maupun tingkat daerah untuk mencapai tujuan pembangunan nasional. Membicarakan tentang aparatur yaitu Pegawai Negeri Sipil (PNS) seakan tidak akan ada habisnya. Mulai dari bagaimana melakukan rasionalisasi mengingat jumlahnya yang sudah terlampau banyak, meningkatkan gaji untuk mencegah praktik korupsi maupun meningkatkan produktivitas yang selama ini boleh dikatakan masih rendah, sampai dengan rencana penghapusan pension. (Adisetiawan, 2017)

Salah satu lembaga/institusi pemerintah yang membawa misi sosial mengutamakan pelayanan medis terhadap masyarakat yaitu Puskesmas. Demikian juga dengan Puskesmas Aro Kecamatan Muara Bulian Kabupaten Batang Hari adalah Unit Pelaksana Teknis Dinas Kesehatan Kabupaten yang bertanggung jawab menyelenggarakan pembangunan kesehatan di suatu wilayah kerja Kecamatan Muara Bulian dengan ketentuan masa kerja lima hari dan jam kerja 37,5 jam per minggu. Dalam usaha pencapaian tujuan Puskesmas perlu didukung oleh kinerja pegawai (PNS) yang baik dalam instansi tersebut, kinerja pegawai adalah hasil kerja yang dapat dicapai oleh seseorang atau sekelompok orang dalam hal suatu organisasi atau instansi, sesuai dengan wewenang dan tangggung jawab masing-masing dalam rangka mencapai tujuan organisasi bersangkutan. Organisasi yang sukses memandang karyawannya sebagai asset, bukan hanya sekedar faktor produksi yang memerlukan biaya. Organisasi melihat dan menganggap karyawan sebagai asset yang harus dikembangkan agar dapat menciptakan nilai bagi orientasi. Dengan memotivasi dan mengembangkan karyawannya, organisasi memperoleh komitmen dan dari karyawanya sekaligus meningkatkan nilai karyawan tersebut, baik bagi organisasi maupun diri karyawan sendiri. (Adisetiawan, 2016)

Karyawan yang memiliki komitmen terhadap perusahaan akan memberikan kontribusi terhada peningkatan produktivitas, pengurangan biaya dan peningkatan kualitas, keunggulan 
yang bersaing yang sangat sulit untuk diperoleh sekaligus. Selain itu karyawan yang memiliki komitmen bisa beradaptasi dengan mudah terhadap visi dan misi organisasi serta berbagai perubahan, sehingga membantu menciptakan harmoni dalam organisasi. Perilaku pemimpin yang mendukung adalah sejauh mana seorang pemimpin melibatkan diri dalam komunikasi dua arah, misalnya mendengar, menyediakan dukungan dan dorongan, memudahkan interaksi dan melibatkan para pengikut dalam pengambilan keputusan dengan bawahannya. Seorang pemimpin harus menggunakan dua per tiga waktu, tenaga dan pikirannya untuk mengawasi dan mendisiplinkan para karyawan yang bermasalah (Thoha, 2007). Puskesmas Desa Aro Kecamatan Muara Bulian merupakan organisasi yang berkecimpung dalam bidang kesehatan dan pelayanan kesehatan masyarakat. Perilaku pemimpin Puskesmas Desa Aro pada dasarnya berorientasi pada visi organisasi.

Pemimpin memiliki peranan dalam mengarahkan ataupun menerangkan kegiatan yang harus dilakukan oleh karyawan. Pemimpin memberikan arahan mengenai hal apa yang harus dilakukan dalam pencapaian tujuan organisasi. Puskesmas Desa Aro dituntut untuk dapat memberikan pelayanan yang memuaskan kepada para masyarakat yang dilayaninya. Prestasi karyawan dapat dinilai dengan kejujuran, kedisiplinan, kreativitas, kerjasama, kepemimpinan, kepribadian kecakapan dan tanggung jawab. Untuk mengetahui pegawai yang berprestasi, maka organisasi mengadakan penilaian prestasi kerja. Perilaku pemimpin dan komitman karyawan sangat berpengaruh dalam usaha pencapaian tujuan organisasi yang optimal dalam peningkatan prestasi kerja dalam suatu organisasi. Tujuan penelitian ini adalah bagaimana pengaruh perilaku pemimpin dan komitmen karyawan secara simultan dan parsial terhadap prestasi kerja karyawan pada Puskesmas Desa Aro kecamatan Muara Bulian (Adisetiawan, 2016)

\section{Tinjauan Pustaka \\ Kepemimpinan}

Kepemimpinan adalah kegiatan untuk mempengaruhi perilaku orang lain, atau seni mempengaruhi perilaku manusia baik perorang maupun kelompok (Thoha, 2007). Menurut Thoha (2007) ada dua bentuk perilaku kepemimpinan dalam suatu organisasi diantaranya adalah perilaku tugas dan perilaku hubungan. Dua bentuk perilaku tugas dan perilaku hubungan merupakan titik pusat dari konsep kepemimpinan situasional. Perilaku tugas adalah suatu perilaku seorang kepemimpinan untuk mengatur dan merumuskan peranan-peranan anggota-anggota kelompok atau para pengikut; menerangkan kegiatan yang harus dikerjakan oleh masing-masing anggota, kapan dilakukan, dimana melaksanakannya dan bagaimana tugas-tugas itu harus dicapai.

\section{Gaya Kepemimpinan}

Gaya kepemimpinan merupakan norma perilaku yang digunakan oleh seseorang pada saat orang tersebut mencoba mempengaruhi perilaku orang lain. Dalam hal ini usaha menyelaraskan persepsi diantara orang yang akan mempengaruhi perilaku dengan orang yang perilakunya akan dipengaruhi menjadi amat penting kedudukannya (Thoha, 2007). Menurut Nawawi (2003) gaya kepemimpinan adalah perilaku atau cara yang dipilih dan dipergunakan pemimpin dalam mempengaruhi pikiran, perasaan, sikap dan perilaku para anggota organisasi atau bawahannya.

\section{Komitmen Karyawan}

Menurut Panggabean (2004) komitmen adalah kuatnya pengenalan dan keterlibatan seseorang dalam suatu organisasi tertentu. Dilain pihak komitmen sebagai kecenderungan untuk terikat dalam garis kegiatan yang konsisten karena menganggap adanya biaya pelaksanaan kegiatan yang lain (berhenti bekerja).

Komitmen karyawan menurut Munandar (2004) terbagi atas tiga komponen, yaitu : 
1. Komponen afektif berkaitan dengan emosional, identifikasi dan keterlibatan pegawai di dalam suatu organisasi. Pegawai dengan afektif tinggi masih bergabung dengan organisasi karena keinginan untuk tetap menjadi anggota organisasi.

2. Komponen normatif merupakan perasaan pegawai tentang kewajiban yang harus diberikan kepada organisasi. Komponen normatif berkembang sebagai hasil dari pengalaman sosialisasi, tergantung dari sejauh apa perasaan kewajiban yang dimiliki pegawai. Komponen normatif menimulkan perasaan kewajiban kepada pegawai untuk memberikan balasan atas apa yang pernah diterimanya dari organisasi.

3. Komponen continuance berarti komponen yang berdasarkan persepsi pegawai tentang kerugian yang akan dihadapinya jika meninggalkan organisasi. Pegawai dengan dasar organisasi tersebut disebabkan karena pegawai tersebut membutuhkan organisasi. Pegawai yang memiliki komitmen organisasi dengan dasar afektif memiliki tingkah laku yang berbeda dengan pegawai dengan dasar continuance. Pegawai yang ingin menjadi anggota akan memiliki keinginan untuk berusaha yang sesuai dengan tujuan organisasi.

\section{Prestasi Kerja}

Prestasi kerja adalah pengorbanan jasa, jasmani dan pikiran untuk menghasilkan barang-barang atau jasa-jasa dengan memperoleh imbalan prestasi tertentu. Prestasi kerja adalah suatu hasil kerja yang dicapai seseorang dalam melaksanakan tugas-tugas yang dibebankan kepadanya (Hasibuan, 2005). Siswanto (2002) prestasi diartikan sebagai hasil akhir yang memuaskan dari pekerjaan yang dilakukan seseorang dapat dilakukan dengan mengukur kinerjanya. Adapun unsur-unsur yang dinilai adalah kejujuran, tanggung jawab, kerjasama, kreativitas dan kedisiplinan.

Kegunaan penilaian prestasi kerja adalah sebagai berikut :

1. Perbaikan prestasi kerja, umpan balik pelaksanaan kerja memungkinkan pegawai, manajer dan departemen personalia dapat membetulkan kegiatan-kegiatan mereka untuk memperbaiki prestasi.

2. Penyesuaian-penyesuaian kompensasi, evaluasi prestasi kerja membantu para pengambil keputusan dalam menentukan kenaikan upah, pemberian bonus dan bentuk kompensasi lainnya.

3. Perencanaan dan Pengembangan Karir, umpan balik prestasi mengarahkan keputusankeputusan karir, yaitu tentang jalur karir tertentu yang harus diteliti.

4. Kesempatan kerja yang adil, penilaian prestasi kerja secara akurat akan menjamin keputusan dan penempatan internal diambil tanpa diskriminasi.

\section{METODE}

Jenis metode ini yang digunakan dalam melakukan penelitian ini adalah metode deksriptif dan verifikatif. Metode deskriptif adalah metode penelitian yang bertujuan untuk menggambarkan, menjelaskan keadaan yang ada di Puskemas Desa Aro Kecamatan Muara Bulian berdasarkan fakta, sifat-sifat populasi dan data-data yang telah dikumpulkan kemudian disusun secara sistematis dan selanjutkan dianalisis untuk diambil kesimpulan. Sedangkan metode verifikatif adalah metode yang digunakan untuk mengetahui kebenaran hipotesis dengan menggunakan perhitungan statistik (Sugiono, 2005). Berbagai mecam jenis data yang dibutuhkan didalam sebuah penelitian ini adalah data primter dan data sekunder.

Metode pengumpulan data yang digunakan dalam penelitian ini adalah sebagai berikut :

1. Penelitian Perpustakaan (Library Research), penelitian kepustakaan dengan mempelajari literature atau membaca buku-buku dan sumber-sumber lain yang relevan denagn masalah yang diteliti. Data yang diperoleh berupa data teoritis.

2. Penelitian Kelapangan (Field Research), field research adalah penelitian yang dilakukan dengan cara mendatangi perusahaan. Penelitian lapangan dilakukann untuk memperoleh data primer yang dilakukan dengan cara sebagai berikut: wawancara, pengamatan (observasi), dan kuesioner 


\section{Populasi dan Sampel}

Populasi adalah sekelompok objek yang akan diteliti (Arikunto, 2006) dan dalam penelitian ini populasi yang dimaksudkan adalah karyawan tetap pada Puskesmas Desa Aro Kecamatan Muara Bulian yang berjumlah 43 orang. Menurut Arikunto (2006), apabila populasi kurang dari 100 maka lebih baik diambil semua sehingga penelitiannya merupakan penelitian dari populasi tetapi jika populasinya besar maka dapat diambil $10-15 \%$ atau $20-25 \%$ atau lebih tergantung waktu, tenaga, dana, luas wilayah dan resiko peneliti. Populasi dalam penelitian ini adalah karyawan tetap pada Puskesmas Desa Aro Kecamatan Muara Bulian yang berjumlah 43 orang. Maka sampel yang diambil adalah $100 \%$ dari populasi yaitu sebanyak 43 orang karyawan.

\section{Alat Analisa \\ Analisa Regresi Berganda}

Analisis regresi ini bertujuan untuk mengetahui ada tidaknya suatu hubungan antara Variabel X1 dan X2 dengan Y dimana ketiga variabel tersebut perilaku pemimpin dan komitmen karyawan sebagai variabel bebas dan prestasi kerja sebagai variabel tidak bebas. Analisis regresi ini dinyatakan dengan persamaan sebagai berikut : $\mathrm{Y}=\mathrm{a}+\mathrm{b} 1 \mathrm{X} 1+\mathrm{b} 2 \mathrm{X} 2$; dimana : $\mathrm{Y}=$ Variabel tidak bebas / dependent (prestasi kerja); X1 = Variabel bebas/ indenpendent (perilaku pemimpin); X2 = Variabel bebas/independent (komitmen karyawan); $\mathrm{a}=$ Bilangan konstanta; b1 = Koefisien regresi perilaku kepemimpinan; b2 $=$ Koefisien regresi komitmen karyawan. Setelah itu digunakan rentang skala yang dala penelitian ini disesuaikan dengan pendapat Durianto (2001) yang didasarkan penggunaan skala likert, yaitu: interval $=\frac{\text { nilai tertinggi-nilai terendah }}{\text { banyakkelas }}=\frac{5-1}{5}=$ 0,8

\section{Uji Validitas}

Validitas menunjukkan sejauh mana ketepatan dan kecermatan suatu alat ukur dalam melakukan fungsi alat ukurnya (Sugiono, 2005). Langkah untuk menentukan data yang sudah valid adalah nilai koefisien korelasi $\mathrm{r}$ hitung lebih besar dari $\mathrm{r}$ table. Tingkat signifikasi (tingkat resiko kesalahan) pada penelitian ini adalah $5 \%$ pada penelitian ini uji validitas akan di lakukan dengan bantuan aplikasi SPSS. Kriteria pengujian

- $\quad$ Jika $r$ hitung $>r$ tabel, berarti variabel tersebut $=$ valid.

- $\quad$ Jika $r$ hitung $<\mathrm{r}$ tabel, berarti variabel tersebut $\neq$ valid.

\section{Uji Reabilitas}

Uji reabilitas menunjukkan pada adanya konsistensi dan stabilitas nilai hasil pada pengukuran tertentu disetiap kali pengukuran dilakukan pada hal yang sama (Jonathan Sarwono, 2012). Untuk mengetahui reabilitas variabel tersebut menggunakan bantuan SPSS. Kriteria pengujian :

- Apabila hasil Cronbach's Alpha > dari taraf signifikansi $50 \%$ atau 0,5 maka variabel tersebut $=$ realiabel.

- Apabila hasil Cronbach's Alpha < dari taraf signifikansi $50 \%$ atau 0,5 maka variabel tersebut $\neq$ realiabel.

\section{Uji Hipotesis}

- Uji T, uji t ini digunakan untuk menguji koefisien regreasi secara individual yaitu pengaruh antara variabel indenpenden (perilaku pemimpin dan komitmen karyawan) dengan variabel dependen (prestasi kerja). Kriteria pengujian : jika uji $\mathrm{t}$ ditolak apabila $\mathrm{t}$ tabel $\leq \mathrm{t}$ hitung $\leq \mathrm{t}$ tabel dan jika uji t diterima apabila $\mathrm{t}_{\text {tabel }} \geq \mathrm{t}_{\text {hitung }} \geq \mathrm{t}_{\text {tabel }}$.

- Uji F, uji goodness of fit dilakukan untuk mengukur ketepatan fungsi regresi dlaam menaksir nilai actual (Ghozali, 2011). Secara sederhana dapat dikatakan bahwa Uji F digunakan untuk menguji pengaruh variabel indenpenden (perilaku pemimpin dan komitmen karyawan) dengan variabel dependen (prestasi kerja) secara bersama-sama (simultan). Dalam bentuk statistic dapat diukur dengan menentukan $\mathrm{F}$ tabel dan $\mathrm{F}$ hitung dengan tingkat kepercayaan $95 \%$ atau taraf signifikansi sebesar $5 \%$ maka: Jika $\mathrm{F}$ hitung > $\mathrm{F}$ tabel, maka berarti masing-masing variabel bebas secara bersama-sama mempunyai 
pengaruh yang signifikansi terhadap variabel terkait. Jika $\mathrm{F}$ hitung $<\mathrm{F}$ tabel, maka berarti masing-masing variabel bebas secara bersama-sama tidak mempunyai pengaruh yang signifikansi terhadap variabel terkait.

Koefisien Determinasi, menghitung determinasi $\mathrm{r}$ diperlukan untuk mengetahui besarnya pengaruh variabel indenpenden $(\mathrm{X})$ terhadap variabel dependen $(\mathrm{Y})$ yang dapat diukur dengan menggunakan rumus : $\mathrm{KD}=\mathrm{r}^{2} \times 100 \%$, dimana $: \mathrm{KD}=$ Koefisien determinasi, $\mathrm{r}^{2}=$ Kuadrat koefisien korelasi. Kriteria untuk analisis koefisien determinasi adalah : jika KD mendekat nol (0), berarti pengaruh variabel indenpenden $(\mathrm{X})$ terhadap dependen $(\mathrm{Y})$ lemah, jika KD mendekat nol (1), berarti pengaruh variabel indenpenden $(\mathrm{X})$ terhadap dependen $(\mathrm{Y})$ kuat.

HASIL

Perilaku Pemimpin Pada Puskesmas Desa Aro Kecamatan Muara Bulian

Tabel 1. Tanggapan Responden Terhadap Perilaku Pemimpin Pada Puskesmas Desa Aro Kecamatan Muara Bulian

$\frac{\text { Perilaku Pemimpin (X1) }}{\text { 1. Pemimpin dapat membina komunikasi }}$

\begin{tabular}{lllllllllllr}
\multicolumn{1}{l}{ SS } & \multicolumn{3}{c}{$\mathbf{S}$} & \multicolumn{2}{c}{$\mathbf{N}$} & \multicolumn{2}{c}{ T } & \multicolumn{2}{c}{ STS } & Indeks \\
- & - & 24 & 96 & 15 & 45 & 4 & 8 & - & - & 3,46 \\
6 & 30 & 23 & 92 & 9 & 27 & 6 & 12 & - & - & 3,74 \\
3 & 15 & 19 & 76 & 19 & 57 & 2 & 4 & - & - & 3,53 \\
2 & 10 & 14 & 56 & 21 & 63 & 6 & 12 & - & - & 3,27 \\
2 & 10 & 18 & 72 & 19 & 57 & 4 & 8 & - & - & 3,41
\end{tabular}
yang baik dengan karyawan ataupun bawahannya

2. Pemimpin bertindak tegas dalam pengaturan karyawan

3. Pemimpin anda memberikan arahan atas apa yang harus dilakukan untuk menyelesaikan pekerjaan dengan baik

4. Pemimpin anda memberlakukan hukuman bagi karyawan yang bekerja tidak seperti yang diinginkan

5. Pemimpin anda melibatkan karyawand dalam proses pembuatan keputusan

Sumber : Data kuesioner diolah

Berdasarkan Tabel 1 tanggapan responden diatas tergambar bahwa yang menjawab ditem pertanyaan nomor 1 berjumlah 3,46 dari 43 responden yang berarti mayoritas tanggapan responden menyatakan setuju. Pertanyaan nomor 2 berjumlah 3,76 dari 43 responden yang berarti mayoritas tanggapan responden menyatakan setuju. Pertanyaan nomor 3 berjumlah 3,53 dari 43 responden yang berarti mayoritas tanggapan responden menyatakan setuju. Pertanyaan nomor 4 berjumlah 3,27 dari 43 responden yang berarti mayoritas tanggapan responden menyatakan netral. Pertanyaan nomor 5 berjumlah 3,41 dari 43 responden yang berarti item pertanyaan nomor 5 mayoritas tanggapan responden menyatakan netral. Jawaban responden mengenai masing-masing indikator pertanyaan dapat diketahui bahwa responden menilai pada pertanyaan nomor 2 memiliki nilai indeks tertinggi berjumlah 3,74 dan berdasarkan jumlah nilai rata-rata dari 5 indikator pertanyaan terhadap perilaku pemimpin memiliki nilai keseluruhan 3,48. Dari jumlah nilai rata-rata tersebut dapat diketahui bahwa responden menjawab setuju.

\section{Komitmen Karyawan Pada Puskesmas Desa Aro Kecamatan Muara Bulian}

Tabel 2. Tanggapan Responden Terhadap Komitmen Karyawan Pada Puskesmas Desa Aro Kecamatan Muara Bulian

\begin{tabular}{cccccccccccrr}
\hline Komitmen Karyawan (X2) & SS & \multicolumn{1}{c}{ S } & \multicolumn{1}{c}{ N } & \multicolumn{2}{c}{ T } & STS & Indeks \\
\hline 1. Saya bersedia melaksanakan tugas- & 2 & 10 & 12 & 48 & 18 & 54 & 6 & 12 & - & - & 2,88 \\
\hline
\end{tabular}


tugas dalam pekerjaan yang

diperintahkan pemimpin demi

tercapainya tujuan organisasi

2. Saya selalu mengerahkan seluruh usaha melibihi yang diharapkan untuk membantu kesuksesan pekerjaan

3. Jika saya akan di keluarkan dari organisasi, akan tetap menjaga rahasia organisasi

4. Saya akan bertahan untuk bekerja pada organisasi ini

5. Saya merasa adanya rasa memiliki terhadap organisasi tempat saya bekerja sekarang ini

Sumber : Data kuesioner diolah

Berdasarkan Tabel 2 tanggapan responden bahwa yang menjawab pertanyaan nomor 1 berjumlah 2,88 dari 43 responden yang berarti mayoritas tanggapan responden menyatakan netral. Pertanyaan nomor 2 berjumlah 3,30 dari 43 responden yang berarti mayoritas tanggapan responden menyatakan netral. Pertanyaan nomor 3 berjumlah 3,55 dari 43 responden yang berarti mayoritas tanggapan responden menyatakan setuju. Pertanyaan nomor 4 berjumlah 3,37 dari 43 responden yang berarti mayoritas tanggapan responden menyatakan netral. Pertanyaan nomor 5 berjumlah 3,60 dari 43 responden yang berarti mayoritas tanggapan responden menyatakan setuju. Jawaban responden mengenai masing-masing indikator pertanyaan dapat diketahui bahwa responden menilai pada pertanyaan nomor 5 memiliki nilai indeks tertinggi berjumlah 3,60 dan berdasarkan jumlah nilai rata-rata dari 5 indikator pertanyaan terhadap komitmen karyawan memiliki nilai keseluruhan 3,34. Dari jumlah nilai rata-rata tersebut dapat diketahui bahwa responden menjawab netral.

\section{Prestasi Kerja Karyawan Pada Puskesmas Desa Aro Kecamatan Muara Bulian}

Tabe1 3. Tanggapan Responden Terhadap Prestasi Kerja Karyawan Pada Puskesmas Desa Aro Kecamatan Muara Bulian

\begin{tabular}{|c|c|c|c|c|c|c|c|c|c|c|c|}
\hline Prestasi Kerja Karyawan (X3) & \multicolumn{2}{|c|}{ SS } & \multicolumn{2}{|c|}{$\mathbf{S}$} & \multicolumn{2}{|c|}{$\mathbf{N}$} & \multicolumn{2}{|c|}{$\mathbf{T}$} & \multicolumn{2}{|c|}{ STS } & Indeks \\
\hline $\begin{array}{l}\text { 1. Pekerjaan yang dibebankan kepada } \\
\text { saya sesuai posisi yang saya duduki }\end{array}$ & 3 & 15 & 14 & 56 & 21 & 63 & 5 & 10 & - & - & 3,34 \\
\hline $\begin{array}{l}\text { 2. Hasil kerja saya cukup akurat, tidak } \\
\text { dapat kesalahan didalamnya }\end{array}$ & 3 & 15 & 14 & 56 & 26 & 78 & 6 & 12 & - & - & 3,74 \\
\hline $\begin{array}{l}\text { 3. Saya menyelesaikan pekerjaan dengan } \\
\text { tepat waktu }\end{array}$ & 4 & 20 & 13 & 52 & 23 & 69 & 3 & 6 & - & - & 3,41 \\
\hline $\begin{array}{l}\text { 4. Saya selalu mengerjakan dengan } \\
\text { sungguh-sungguh apa yang menjadi } \\
\text { tanggung jawab saya }\end{array}$ & 2 & 10 & 18 & 72 & 20 & 60 & 3 & 6 & - & - & 3,44 \\
\hline $\begin{array}{l}\text { 5. Saya bisa bekerja sama baik dengan } \\
\text { orang lain dalam penyelesaian tugas } \\
\text { kelompok }\end{array}$ & 3 & 15 & 20 & 80 & 15 & 45 & 5 & 10 & - & - & 3,48 \\
\hline Jumlah rata-rata & & & & & & & & & & & 3,48 \\
\hline
\end{tabular}

Sumber : Data kuesioner diolah

Berdasarkan Tabel 3 tanggapan responden diatas tergambar bahwa pertanyaan nomor 1 berjumlah 3,34 dari 43 responden yang berarti mayoritas tanggapan responden menyatakan netral. Pertanyaan nomor 2 berjumlah 3,74 dari 43 responden yang berarti mayoritas tanggapan 
responden menyatakan netral. Pertanyaan nomor 3 berjumlah 3,41 dari 43 responden yang berarti mayoritas tanggapan responden menyatakan netral. Pertanyaan nomor 4 berjumlah 3,44 dari 43 responden yang berarti mayoritas tanggapan responden menyatakan netral. Pertanyaan nomor 5 berjumlah 3,48 dari 43 responden yang berarti mayoritas tanggapan responden menyatakan setuju. Jawaban responden mengenai masing-masing indikator pertanyaan dapat diketahui bahwa responden menilai pada pertanyaan nomor 2 memiliki nilai indeks tertinggi berjumlah 3,74 dan berdasarkan jumlah nilai rata-rata dari 5 indikator pertanyaan terhadap prestasi kerja karyawan memiliki nilai keseluruhan 3,48. Dari jumlah nilai rata-rata tersebut dapat diketahui bahwa responden menjawab netral.

\section{Pengaruh Perilaku Pemimpin dan Komitmen Karyawan Terhadap Prestasi Kerja Karyawan Pada Puskesmas Desa Aro Kecamatan Muara Bulian Uji Validitas}

Tabel 4. Uji Validitas

\begin{tabular}{ccccc}
\hline Variabel & Item Pertanyaan & r Hitung & r Tabel & Keterangan \\
\hline \multirow{5}{*}{ Perilaku Pemimpin } & 1 & 0,577 & 0,2940 & Valid \\
& 2 & 0,695 & 0,2940 & Valid \\
& 3 & 0,577 & 0,2940 & Valid \\
\multirow{5}{*}{ Komitmen Karyawan } & 4 & 0,741 & 0,2940 & Valid \\
& 5 & 0,540 & 0,2940 & Valid \\
& 1 & 0,730 & 0,2940 & Valid \\
\multirow{3}{*}{ Prestasi Kerja } & 2 & 0,475 & 0,2940 & Valid \\
& 4 & 0,647 & 0,2940 & Valid \\
& 5 & 0,627 & 0,2940 & Valid \\
& 1 & 0,425 & 0,2940 & Valid \\
& 2 & 0,698 & 0,2940 & Valid \\
& 3 & 0,715 & 0,2940 & Valid \\
& 4 & 0,470 & 0,2940 & Valid \\
& 5 & 0,497 & 0,2940 & Valid \\
\hline
\end{tabular}

Sumber : Data kuesioner diolah

Berdasarkan Tabel 4 di atas, dapat diketahui bahwa semua item pertanyaan secara keseluruhan dinyatakan valid dan dapat digunakan untuk mendukung penelitian ini.

\section{Uji Reliabilitas}

Nilai Reliabilitas diperoleh dengan melihat pada kontak output perhitungan. Nilai alpha yang dihasilkan tinggal di tafsirkan sesuai kriteria perbandingan yang digunakan. Sebagai tafsiran umum, jika nilai reliabilitas $>r$ tabel dapat dikatakan bahwa instrument yang digunakan sudah reliable. Dari tabel hasil uji realibilitas dengan jumlah responden sebanyak 43 orang dan taraf signifikan $5 \%$ maka di peroleh nilai $r$ tabel sebesar 0,05. Maka dari hasil analisa diatas secara keseluruhan pertanyaan dari kuesioner adalah sebagai berikut :

Tabel 5. Uji Reliabilitas

\begin{tabular}{lllll}
\hline No & Variabel & Cronbach's Alpha & r Tabel & Keterangan \\
\hline 1 & Perilaku Pemimpin & 0,616 & 0,5 & Reliabel \\
2 & Komitmen karyawan & 0,518 & 0,5 & Reliabel \\
3 & Prestasi Kerja & 0,543 & 0,5 & Reliabel \\
\hline
\end{tabular}

Sumber : Data kuesioner diolah 
Berdasarkan Tabel 5 di atas, dapat diketahui bahwa keseluruhan variabel lebih besar nilai Cronbach's Alpha dari pada tingkat signifikannya. Hal ini bahwa keseluruhan variabel dinyatakan reliable dan dapat diterapkan dalam penelitian ini.

\section{Analisis Regresi Linear Berganda}

Regresi Linear Berganda

Perhitungan SPSS tersebut maka didapatlah persamaan regresi linear berganda $\mathrm{Y}=1,357$ $+0,477 \mathrm{X}_{1}+0,446 \mathrm{X}_{2}$. Persamaan regresi linear berganda tersebut didapatlah bahwa nilai a (konstanta) sebesar 1,375 dan nilai $b_{1}$ koefisien untuk perilaku pemimpin sebesar 0,477 , nilai $b_{2}$ koefisien untuk komitmen karyawan 0,466. Hal ini berarti terdapat pengaruh positif dalam penelitian ini. Persamaan diatas juga dapat diartikan sebagai berikut :

- $\quad a=1,357$ artinya apabila variabel perilaku pemimpin dan komitmen karyawan nol maka variabel prestasi kerja karyawan sebesar 1,357.

- $\quad b_{1}=$ artinya jika terjadi kenaikan satu satuan variabel perilaku pemimpin, akan menaikkan prestasi kerja sebesar 0,477. Dengan asumsi variabel prestasi kerja tetap.

- $\quad b_{2}=$ artinya jika terjadi kenaikan satu satuan dari variabel komitmen karyawan, akan menaikkan prestasi kerja sebesar 0,466. Dengan asumsi variabel prestasi kerja tetap.

\section{Uji F}

Perhitungan SPSS diketahui bahwa nila f hitung sebesar 69,829 dan nilai f tabel sebesar 3,23. Ini berarti bahwa nilai f hitung $>\mathrm{f}$ tabel $(69,829>3,23)$. Ini berarti bahwa perilaku pemimpin dan komitmen karyawan mempengaruhi variabel prestasi kerja karyawan secara simultan (bersama-sama).

\section{Uji t}

Uji $\mathrm{t}$ ini digunakan untuk mengkaji koefisien regresi secara individual yaitu antara variabel indenpenden dengan variabel dependen. Dari hasil pengolahan pada tabel diatas, dapat diketahui bahwa :

- $\quad$ Nilai $r$ hitung dari koefisien regresi untuk perilaku pemimpin sebesar 4,001. Karena t hitung $(4,001)>\mathrm{t}$ tabel $(1,68195)$ maka Ho di terima jadi dapat disimpulkan bahwa perilaku pemimpin berpengaruh signifikan terhadap prestasi kerja karyawan pada Puskesmas Desa Aro Kecamatan Muara Bulian.

- Nilai t hitung dari koefisien regresi untuk komitmen karyawan sebesar 3,626. Karena $t$ hitung $(3,626)>t$ tabel $(1,68195)$ maka Ho di terima jadi dapat disimpulkan bahwa variabel komitmen karyawan berpengaruh signifikan terhadap prestasi kerja karyawan pada Puskesmas Desa Aro Kecamatan Muara Bulian.

\section{Koefisien Determinasi $\left(\boldsymbol{R}^{2}\right)$}

Perhitungan $R^{2}$ ( $R$ Square) dapat diketahui nilai $R^{2}$ ( $R$ Square) sebesar 0,766. Ini berarti bahwa variabel perilaku pemimpin dan komitmen karyawan memberikan pengaruh sebesar 76,6 $\%$ terhadap prestasi kerja pada Puskesmas Desa Aro Kecamatan Muara Bulian. Sedangkan 23,4 $\%$ lagi dipengaruhi oleh variabel-variabel lain yang tidak diteliti dalam penelitian ini.

\section{SIMPULAN}

1. Variabel perilaku pemimpin $\left(\mathrm{X}_{1}\right)$ jawaban responden berdasarkan 5 indikator pertanyaan dapat diketahui bahwa responden menilai pertanyaan nomor 2 memiliki indikator nilai tertinggi dengan jumlah 3,74 dan berdasarkan jumlah nilai rata-rata dari 5 indikator pertanyaan berjumlah 3,48 dari jumlah nilai rata-rata dapat diketahui responden menjawab setuju.

2. Variabel komitmen karyawan $\left(\mathrm{X}_{2}\right)$ dari jawaban responden berdasarkan 5 indikator pertanyaan dapat diketahui bahwa responden menilai pertanyaan nomor 5 memiliki indikator nilai tertinggi dengan jumlah 3,60 dan berdasarkan jumlah nilai rata-rata dari 5 
indikator pertanyaan berjumlah 3,34 dari jumlah nilai rata-rata dapat diketahui responden menjawab netral.

3. Variabel prestasi kerja $\left(\mathrm{X}_{3}\right)$ digunakan pendapat responden melalui jawaban kuesioner. Indicator pertanyaan mengenai penyelesaian pekerjaan, bekerja dengan sungguh-sungguh dan bisa bekerja sama dengan anggota organisasi dalam penyelesaian tugas-tugas organisasi. Dari jawaban responden berdasarkan 5 indikator pertanyaan dapat diketahui bahwa responden menilai pertanyaan nomor 2 memiliki indikator nilai tertinggi dengan jumlah 3,74 dan berdasarkan jumlah nilai rata-rata dari 5 indikator pertanyaan berjumlah 3,48 dari jumlah nilai rata-rata dapat diketahui responden menjawab netral.

4. Berdasarkan uji $\mathrm{t}$ (sendiri-sendiri) bahwa perilaku pemimpin $\left(\mathrm{X}_{1}\right)$ memberikan pengaruh yang positif terhadap prestasi kerja $(\mathrm{Y})$ yaitu $4,001>1,68195)$ dengan tingkat signifikan $(0,000<0,005)$ dan variabel komitmen karyawan $\left(\mathrm{X}_{2}\right)$ juga memberikan pengaruh yang positif terhadap prestasi kerja $(\mathrm{Y})$ yaitu $(3,626>1,68195)$ dengan tingkat signifikan $(0,000<$ $0,005)$ dan melalui uji $f$ yaitu pengujian secara simultan atau bersama-sama variabel perilaku pemimpin $\left(\mathrm{X}_{1}\right)$ dan komitmen karyawan $\left(\left(\mathrm{X}_{2}\right)\right.$ memiliki pengaruh yang signifikan terhadap prestasi kerja $(\mathrm{Y})$ yaitu $(69,829>3,23)$ dengan signifikan $(0,000<0,005)$ serta dari perhitungan koefisien determinasi $\left(\mathrm{R}^{2}\right)$ sebesar 0,766 yang menunjukkan bahwa antara perilaku pemimpin $\left(\mathrm{X}_{1}\right)$ dan komitmen karyawan $\left(\mathrm{X}_{2}\right)$ secara bersama-sama menjelaskan terhadap prestasi kerja (Y) pada Puskesmas Desa Aro Kecamatan Muara Bulian sebesa 76,6 $\%$ sedangkan sisanya $23,4 \%$ dipengaruhi oleh variabel lain yang tidak diteliti.

\section{DAFTAR PUSTAKA}

Adisetiawan, R., 2017, Kajian Persepsi Pemilik Usaha Kecil dan Menengah (UKM) terhadap Laporan Keuangan, Jurnal Ilmiah Universitas Batanghari Jambi, 13(4), 162-173

Adisetiawan, R., 2016, Faktor yang Mempengaruhi Lulusan SMA dalam Memilih Fakultas Ekonomi Program Studi Manajemen Universitas Batanghari, Jurnal Ilmiah Universitas Batanghari Jambi, 16(3), 1-11

Arikunto, Suharsimi. 2006. Prosedur Penelitian Suatu Pendekatan Praktek, Edisi Revisi,. Rineka Cipta, Jakarta.

Ghozali, Imam. 2011, Aplikasi Analisis Multivariat dengan Program SPSS, Badan Penerbit Universitas Diponegoro, Semarang.

Hasibuan, H. Malayu SP, 2005, MSDM, Jakarta Bumi Akasara

Panggabean, Mutiara S., 2004, MSDM, Edisi 2, Bogor: Ghalia Indonesia

Munandar, Utami, 2004, Pengembangan Kreativitas Anak Berbakat, Jakarta: Rineka Cipta

Nawawi. Hadari. 2003. Kepemimpinan Mengefektifkan Organisasi. Yogyakarta : Gajah Mada University Press.

Sugiono. 2005. Metode penelitian Kuantitatif, Kualitatif dan Kombinasi (Mixed Methods). Cetakan Ketiga. Bandung : Alfabeta.

Siswanto, Sastrohadiwiryo., B, 2002, Manajamen Tenaga Kerja Indonesia: Pendekatan Administratif dan Operasional, Bumi Aksara

Thoha, Miftah. 2007. Kepemimpinan Dalam Manajemen. Edisi Pertama. PT. Raja Grafindo Persada. Jakarta. 